\title{
Impacts of long-term nitrogen addition on nitrous oxide in a temperate grassland
}

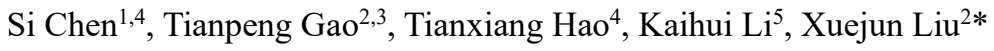 \\ ${ }^{1}$ Lanzhou City University, Lanzhou 730070, China. \\ ${ }^{2}$ School of Biological and Environmental Engineering, Xi'an University, Xi'an 710065, China \\ ${ }^{3}$ Engineering Center for Pollution Control and Ecological Restoration in Mining of Gansu Provinc- \\ e, Lanzhou City University, Lanzhou 730070, China \\ ${ }^{4}$ Key Laboratory of Plant-Soil Interactions of MOE and Beijing Key Laboratory of Farmland Pollution Prevention and Remediation, \\ College of Resources and Environmental Sciences, China Agricultural University, Beijing 100193, China. \\ ${ }^{5}$ Key Laboratory of Biogeography and Bioresource in Arid Land, Xinjiang Institute of Ecology and Geography, Chinese Academy of \\ Sciences, Urumqi 830011, China
}

\begin{abstract}
Atmospheric nitrogen $(\mathrm{N})$ deposition has increased dramatically due to increased human activities since the industrial revolution. However, it is still unclear what the responses of soil nitrous oxide $\left(\mathrm{N}_{2} \mathrm{O}\right)$ is to long-term elevated $\mathrm{N}$ deposition in a temperate grassland. Here, we conducted an in situ field experiment to investigate these responses to long-term high $\mathrm{N}$ addition on a temperate steppe in Inner Mongolia, China, from April 2017 to October 2018. Soil $\mathrm{N}_{2} \mathrm{O}$ emissions significantly increased by long-term $\mathrm{N}$ addition, use of structural equation modeling (SEM) showed that topsoil (0-5 cm) $\mathrm{NH}_{4}{ }^{+}-\mathrm{N}$ content was the most important limiting factor for $\mathrm{N}_{2} \mathrm{O}$ emission. Our results indicate that long-term high $\mathrm{N}$ addition showed a significantly increase in $\mathrm{N}_{2} \mathrm{O}$ emission in this temperate grassland.
\end{abstract}

\section{Introduction}

Anthropogenic nitrogen $(\mathrm{N})$ enrichment and global warming are primary components of global change. $\mathrm{N}$ deposition to terrestrial ecosystems has increased from 17.4 $\mathrm{Tg} \mathrm{N} \mathrm{yr}^{-1}$ in late $1860 \mathrm{~s}$ to $187 \mathrm{Tg} \mathrm{N} \mathrm{yr}-1$ in the 2005 , and is expected to increase to $200 \mathrm{Tg} \mathrm{N} \cdot \mathrm{yr}^{-1}$ in $2050^{[1]}$. This in natural ecosystems has many negative effects on ecosystem services: biodiversity loss, nutrient imbalance, and increased greenhouse gases (GHGs) emissions ${ }^{[2,3]}$

In Inner Mongolia grassland occupies a large area of northern China and $13 \%$ of the global grassland area ${ }^{[4]}$. However, models of $\mathrm{N}_{2} \mathrm{O}$ emission with the $\mathrm{N}$ deposition shows $\mathrm{N}_{2} \mathrm{O}$ emission increased as exponential and unimodal response ${ }^{[5,6]}$, when the $\mathrm{N}$ reached biological threshold, $\mathrm{N}_{2} \mathrm{O}$ emission transitions to the $\mathrm{N}$ saturation stage, at this stage, higher $\mathrm{N}$ could not increase $\mathrm{N}_{2} \mathrm{O}$ emission, including in some temperate and subtropical grasslands $s^{[7]}$.

$\mathrm{N}$ saturation model believes that in natural ecosystems, enhanced $\mathrm{N}$ deposition would produce more soil $\mathrm{N}_{2} \mathrm{O}^{[8]}$, but recent study on steppe showed that influence of significant climatic factors on $\mathrm{N}_{2} \mathrm{O}$ depends on the ability to alleviate $\mathrm{N}_{2} \mathrm{O}$ emission limited by soil "nitrogen deficiency" ${ }^{[9,10]}$. Therefore, the effects of long-term $\mathrm{N}$ addition on $\mathrm{N}_{2} \mathrm{O}$ emission are still uncertain. In another way, $\mathrm{N}$ enrichment was always accompanied by the changes in soil properties like soil acidification, available $\mathrm{N}$ and $\mathrm{C}$ states, as well as vegetation of ecosystem. Therefore, it is also valuable to find the complex response of $\mathrm{N}_{2} \mathrm{O}$ fluxes of soil to variations in multiple indirect factors caused by $\mathrm{N}$ deposition of grassland ${ }^{[11]}$.

Therefore, we set up a long-term in stiu experiment in Inner Mongolia, China in 2005, which has caused severe soil acidification after 13 years of $\mathrm{N}$ fertilization, and significant changes in soil properties ${ }^{[12]}$. To assess how these changes have affected soil $\mathrm{N}_{2} \mathrm{O}$ emission, we measured $\mathrm{N}_{2} \mathrm{O}$ fluxes with high frequency from May 2017 to October 2018, with the objectives of: (i) quantifying the response of the $\mathrm{N}_{2} \mathrm{O}$ emission to long-term increased $\mathrm{N}$ addition, and (ii) identifying the main controlling factors of $\mathrm{N}_{2} \mathrm{O}$ caused by long-term increased $\mathrm{N}$ addition.

\section{Experimental methods}

\subsection{Site description}

This study was conducted in a semi-arid temperate grassland in Duolun County $\left(116^{\circ} 17 \mathrm{E}, 42^{\circ} 02 \mathrm{~N}\right.$, elevation $1324 \mathrm{~m}$ ), northeastern of Xilingol of Inner Mongolia, China. The rainfall and air temperature average $316 \mathrm{~mm}$ and $3.3^{\circ} \mathrm{C}$ between 2006 to 2016 , and $81 \%$ of total

\footnotetext{
* Corresponding author: Xuejun Liu, Emil: liu310@cau.edu.cn
} 
precipitation in growing season (May $10^{\text {th }}$ to August $30^{\text {th }}$; Fig.1(a)). The local $\mathrm{N}$ deposition has increased to $15.4 \mathrm{~kg}$ $\mathrm{N} \mathrm{ha}^{-1} \mathrm{yr}^{-1}$ in 2015 , consist with $58 \%$ as $\mathrm{NH}_{4}^{+}$and $42 \%$ as $\mathrm{NO}_{3}{ }^{-} .0-10 \mathrm{~cm}$ layer soil $\mathrm{pH}$ and bulk density are 7.12 and $1.31 \mathrm{~g} \mathrm{~cm}^{-1}$. Soil total $\mathrm{N}$ and total $\mathrm{P}$ contents are $12.3 \mathrm{~g}$ $\mathrm{kg}^{-1}$ and $1.3 \mathrm{~g} \mathrm{~kg}^{-1}$, organic carbon and $\mathrm{C}: \mathrm{N}$ are $0.28 \mathrm{~g} \mathrm{~kg}^{-}$ 1 and 21 , respectively.

\subsection{Experimental treatments}

The experiment was designed with three $\mathrm{N}$ addition treatments of four replicates that were arranged randomly. Plot area was $5 \times 5 \mathrm{~m}$ with a $1 \mathrm{~m}$ wide buffer zone. Ammonium nitrate was applied as foliar fertilizer at simulated $\mathrm{N}$ deposition rates of $\mathrm{N}_{0}\left(0 \mathrm{~kg} \mathrm{~N} \mathrm{ha}^{-1} \mathrm{yr}^{-1}\right), \mathrm{N}_{30}$ $\left(30 \mathrm{~kg} \mathrm{~N} \mathrm{ha}^{-1} \mathrm{yr}^{-1}\right)$ and $\mathrm{N}_{60}\left(60 \mathrm{~kg} \mathrm{~N} \mathrm{ha}^{-1} \mathrm{yr}^{-1}\right)$. The fertilizer was divided into 2 equal portions, and sprayed evenly in mid-June and mid-July every year $\left(15^{\text {th }}\right.$ June and $17^{\text {th }}$ July in 2017). $\mathrm{N}_{2} \mathrm{O}$ was measured from May 2017 to October 2018 .

\subsection{Measurements method}

Static closed chamber technique was used to measure $\mathrm{N}_{2} \mathrm{O}$ fluxes. The chambers were made of removable top and previously-installed stainless steel (into soil for $10 \mathrm{~cm}$ ). Sampling was conducted between 10:00 am and 12:00 pm. Gases fluxes were collected once or twice a week. Gas samples were injected into $50 \mathrm{ml}$, and were analyzed using a gas chromatograph (GC; Agilent 7890A, Agilent Technologies, Santa Clara, CA, USA) equipped with an electron capture detector for determination of $\mathrm{N}_{2} \mathrm{O}^{[13,14]}$.

Fresh soil samples were extracted in $0.01 \mathrm{~mol} \mathrm{~L}^{-1}$ $\mathrm{CaCl}_{2}$ solution and shaken for 1 hour. The suspension was analyzed for nitrate and ammonium concentration using a continuous-flow auto-analyzer (Seal AA3, Germany). Dissolved organic carbon (DOC) was extracted from the fresh soil sub-samples by shaking with deionized water, and filtered at $0.45 \mu \mathrm{m}$ and the filtrate analyzed with a TOC analyzer (multi N/C 3100, Jena, Germany). Soil pH was measured using a pH Meter (Seven Easy, MettlerToledo, Switzerland). Soil water content and temperature in the $0-5 \mathrm{~cm}$ layer were measured using a TDR probe.

\section{Statistical analyses}

Treatment enrichment effects on soil $\mathrm{pH}, \mathrm{NO}_{3}^{-}-\mathrm{N}, \mathrm{NH}_{4}^{+}-$ $\mathrm{N}$ content, DOC, total emission of $\mathrm{N}_{2} \mathrm{O}$ were assessed using a least significant difference test (LSD, $P<0.05)$. In addition, the relationships between fluxes of $\mathrm{N}_{2} \mathrm{O}$ with soil moisture, soil $\mathrm{NO}_{3}{ }^{-}-\mathrm{N}$ and $\mathrm{NH}_{4}{ }^{+}-\mathrm{N}$ contents, $\mathrm{pH}$ were analyzed using structural equation models (SEM). Oneway repeated measures analysis of variance was used to analysis. All statistical analyses were conducted using SPSS (version 20.0) with statistically significant differences set at $\mathrm{p}<0.05$. SEM analyses were carried out using AMOS 22.0. All figures were drawn using Sigmaplot (version 13.0).

\section{Results}

Long-term high $\mathrm{N}$ addition increased significnatly soil $\mathrm{NO}_{3}^{-}-\mathrm{N}$, DOC content (except in $\mathrm{N}_{30}$ Treatment), and decreased $\mathrm{pH}$ significantly by long-term $\mathrm{N}$ addition, but has no effect on $\mathrm{NH}_{4}{ }^{+}$content.

Small $\mathrm{N}_{2} \mathrm{O}$ emissions were observed from $\mathrm{N}_{0}$ plots, ranging from 0.59 to $16.32 \mu \mathrm{g} \mathrm{N} \mathrm{m}^{-2} \mathrm{~h}^{-1}$ (average annual $4.45 \pm 0.34 \mu \mathrm{g} \mathrm{N} \mathrm{m}^{-2} \mathrm{~h}^{-1}$ ) (Fig. 1b). Long-term increased $\mathrm{N}$ addition significantly increased the $\mathrm{N}_{2} \mathrm{O}$ emissions $(\mathrm{P}<$ 0.001) (Fig 1b; Table 3), with average annual emissions from $\mathrm{N}_{30}$ and $\mathrm{N}_{60}$ plots of $9.49 \pm 0.79$ and $20.35 \pm 3.23 \mu \mathrm{g}$ $\mathrm{N} \mathrm{m}^{-2} \mathrm{~h}^{-1}$, respectively (Fig $1 \mathrm{~b}$ ). The SEM showed that soil moisture had a significantly positive correlation with soil $\mathrm{N}_{2} \mathrm{O}$ emissions both directly and indirectly, and that soil $\mathrm{NH}_{4}{ }^{+}-\mathrm{N}$ content was the most important influencing factor (Fig. 2). Notably, neither soil pH or DOC had a significant impact on $\mathrm{N}_{2} \mathrm{O}$ emissions (Fig. 2).

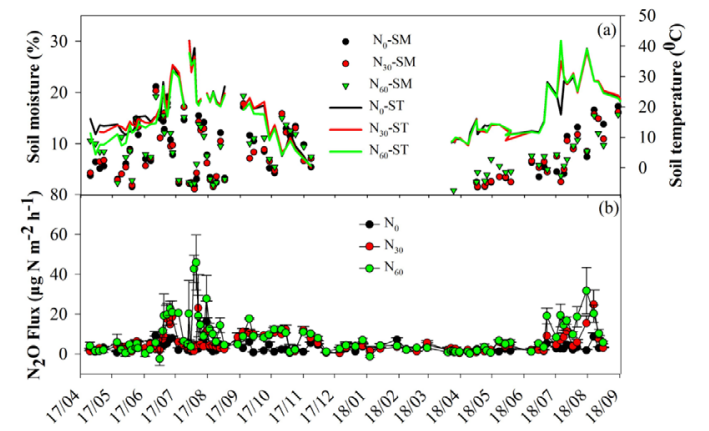

Figure 1. The Variation from April 2017 to October 2018 in soil moisture and soil temperature $\left({ }^{\circ} \mathrm{C}\right)(\mathrm{a})$, and fluxes in $\mathrm{N}_{2} \mathrm{O}$ (b) (mean, n=4) in an Inner Mongolian grassland.

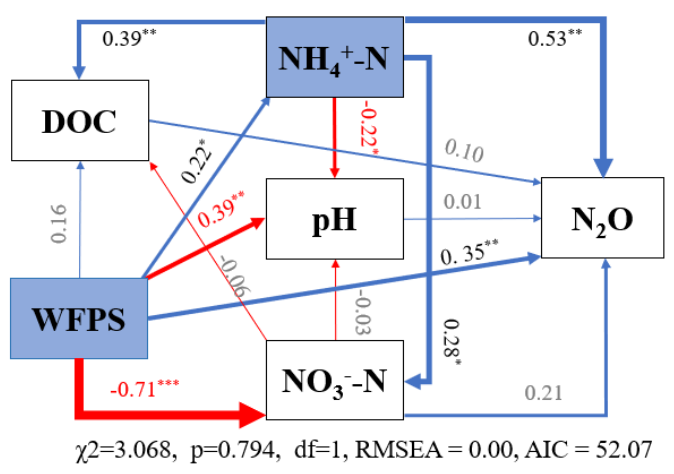

Figure 2. The effects on $\mathrm{N}_{2} \mathrm{O}$ emission $(\mathrm{n}=28)$ of soil moisture, temperature, $\mathrm{pH}$, soil $\mathrm{NO}_{3}{ }^{-}-\mathrm{N}$ content and $\mathrm{NH}_{4}{ }^{+}-\mathrm{N}$ content as tested by structural equation modeling (SEM). Single-headed arrows showed that the impact of different significant controls on $\mathrm{N}_{2} \mathrm{O}$ emission was analyzed. The blue arrows represent positive effects, and red arrows negative effects. The width of the arrows indicated the strength of the relationship. The numbers are standardized path coefficients, which show the significance of the variables in the model. Goodness-of-fit statistics for the model are shown below the model. *, ** and *** indicate significant effect at $\mathrm{P}<0.05, \mathrm{P}<$ 0.01 , and $\mathrm{P}<0.001$, respectively. 
Table1. The variation in $\mathrm{NO}_{3}{ }^{-}-\mathrm{N}, \mathrm{NH}_{4}{ }^{+}-\mathrm{N}$, soil $\mathrm{pH}$, dissolved organic carbon (DOC) of topsoil $(0-5 \mathrm{~cm})$ with the treatments in August 2017. Values in the same column with different letters indicate significant differences $(\mathrm{P}<0.05)$

\begin{tabular}{ccccc}
\hline Treatments & $\mathrm{NH}_{4}{ }^{+}-\mathrm{N}\left(\mathrm{mg} \mathrm{kg}^{-1}\right)$ & $\mathrm{NO}_{3}{ }^{-} \mathrm{N}\left(\mathrm{mg} \mathrm{kg}^{-1}\right)$ & $\mathrm{pH}$ & DOC $\left(\mathrm{mg} \mathrm{kg}^{-1}\right)$ \\
\hline $\mathrm{N}_{0}$ & $5.30 \pm 2.82 \mathrm{a}$ & $11.65 \pm 5.28 \mathrm{a}$ & $6.32 \pm 0.09 \mathrm{~b}$ & $68.46 \pm 4.01 \mathrm{a}$ \\
$\mathrm{N}_{30}$ & $5.97 \pm 0.95 \mathrm{a}$ & $17.29 \pm 2.05 \mathrm{a}$ & $5.91 \pm 0.07 \mathrm{a}$ & $75.83 \pm 8.89 \mathrm{a}$ \\
$\mathrm{N}_{60}$ & $6.79 \pm 1.30 \mathrm{a}$ & $19.82 \pm 3.90 \mathrm{~b}$ & $5.94 \pm 0.35 \mathrm{a}$ & $82.59 \pm 8.06 \mathrm{~b}$ \\
\hline
\end{tabular}

Table2. Repeated measures ANOVA analysis of variance with $\mathrm{F}$ and $\mathrm{P}$ values of the total effects of long-term nitrogen $(\mathrm{N})$ addition on $\mathrm{N}_{2} \mathrm{O}$ emissions in long-term $\mathrm{N}$ addition; $\mathrm{n}$ indicates sample size.

\begin{tabular}{llll}
\hline $\begin{array}{l}\text { Source of } \\
\text { variation }\end{array}$ & \multicolumn{3}{c}{$\mathrm{N}_{2} \mathrm{O}$} \\
\cline { 2 - 4 } & \multicolumn{1}{c}{$\mathrm{df}$} & \multicolumn{1}{c}{$\mathrm{F}$} & \multicolumn{1}{c}{$\mathrm{P}$} \\
\hline Date & 1.834 & 9.861 & $0.009^{* *}$ \\
$\mathrm{~N}$ & 1 & 101.127 & $<0.001^{* *}$ \\
Date*N & 1.834 & 2.603 & 0.142 \\
\hline
\end{tabular}

\section{Discussion}

$\mathrm{N}_{2} \mathrm{O}$ emissions of the temperate grassland (Fig. 1b; Table 3 ), acted as a small source of $\mathrm{N}_{2} \mathrm{O}$ and the cumulative emission of $\mathrm{N}_{2} \mathrm{O}$ from $\mathrm{N}_{0}$ plots is $0.37 \mathrm{~kg} \mathrm{~N} \mathrm{ha}^{-1}$ (Fig. 1b), higher than that from other ungrazed steppes in Inner Mongolia (below $0.28 \mathrm{~kg} \mathrm{~N} \mathrm{ha}^{-1}$ ) ${ }^{[16]}$. $\mathrm{N}_{2} \mathrm{O}$ emissions was triggered by the day following fertilization, and the peaks lasted about 20 days and the emissions fell to the baseline (Fig. 1b), which was related to the dynamics of soil mineral $\mathrm{N}$ (Table 1). The SEM showed that $\mathrm{NH}_{4}{ }^{+}-\mathrm{N}$ was the most important controlling factor for $\mathrm{N}_{2} \mathrm{O}$ emission rather than $\mathrm{NO}_{3}-\mathrm{N}$ or $\mathrm{pH}$ (Fig. 2), indicated that $\mathrm{N}_{2} \mathrm{O}$ emission was mainly as byproduct of soil ammonia oxidation. Dry weather and the sandy texture (sand 62.8\%) had been keeping soil WFPS below 30\% (Fig.1a) over the observed period, in that conditions $\mathrm{N}_{2} \mathrm{O}$ by denitrification produced much less (WFPS $\leq 70 \%)^{[17]}$. Recent studies suggested that in a typical steppe, long-term nitrogen fertilization and soil $\mathrm{pH}$ could have contrasting effects on ammonia oxidizing microorganisms ${ }^{[18]}$, our result showed that $\mathrm{pH}$ had less influence to $\mathrm{N}_{2} \mathrm{O}$, that was primarily due to N-reduced $\mathrm{pH}$ did not dramatically shifted $\mathrm{N}$ inducing function and diversity of ammonia oxidizers of grassland $^{[19]}$.

\section{Conclusion}

Atmospheric $\mathrm{N}$ deposition has dynamically increased in recent years, which will significantly affect the $\mathrm{N}_{2} \mathrm{O}$ balance in grassland ecosystems. Long-term (13 year) increased $\mathrm{N}$ addition significantly increased $\mathrm{N}_{2} \mathrm{O}$ emission. Soil $\mathrm{NH}_{4}{ }^{+}-\mathrm{N}$ content and soil moisture were the most important limiting factors for $\mathrm{N}_{2} \mathrm{O}$ emissions, $\mathrm{pH}$ had less influence to $\mathrm{N}_{2} \mathrm{O}$. We conclude that $\mathrm{N}_{2} \mathrm{O}$ emission would be enhanced by long-term increased $\mathrm{N}$ deposition, which will have an important effect for climate change with elevating atmospheric $\mathrm{N}$ deposition in future.

\section{Acknowledgments}

This work was supported by the Doctoral Research Fund of Lanzhou City University (LZCU-BS201943), Natural Science Foundation of China(NSFC 318601 76), Key Research and

Development Program of Gansu Province (20YF3FA037 ), Key Research and Development Program of Shanxi Pr ovince (2020ZDLSF0606) and XAWLKYTD012 the Natural Science Foundation of Gansu Province, China (21JR1RA319). Chinese Key State Research and Development Programme (2017YFC0210100), China National Funds for Distinguished Young Scientists (Grant No. 41425007), and the UK Newton Fund through the BBSRC project 'China Virtual Joint Centre for Improved N Agronomy (CINAG)’ (BB/N013468/1)

\section{References}

1. Galloway, J. N., Townsend, A. R., Erisman, J. W., Bekunda, M., Cai, Z. C., Freney, J.R., Martinelli, L. A., Seitzinger, S. P., Sutton, M. A. (2008). Transformation of the nitrogen cycle: recent trends, questions, and potential solutions. Science, 320, 889982.

2. Aber, J., McDowell, W., Nadelhoffer, K., Magill, A., Berntson, G., Kamakea, M., McNulty, S., Currie, W., Rustad, L., Fernandez, I. (1998). Nitrogen saturation in temperate forest ecosystems - Hypotheses revisited. Bioscience, 48, 912-93.

3. Lu, X. K., Mao, Q. G., Gilliam, F. S., Luo, Y. Q., Mo, J. M. (2015). Nitrogen deposition contributes to soil acidification in tropical ecosystems. Global Change Biology, 20, 3790-3801.

4. Wang, Y. S., Xue, M., Zheng, X. H., Ji, B. M., Du, R., Wang, Y. F. (2005). Effects of environmental factors on $\mathrm{N} 2 \mathrm{O}$ emission from and $\mathrm{CH} 4$ uptake by the typical grasslands in the Inner Mongolia, Chemosphere, 58(2), 205-215.

5. Hao, T. X., Song, L., Goulding, K., Zhang, F. S. and Liu, X. J. (2018). Cumulative and partially recoverable impacts of nitrogen addition on a temperate steppe. Ecology Application, 28, 237-248.

6. Zhang, W., Liu, C. Y., Zheng, X. H., Fu, Y. F., Hu, X. X., Cao, G. M., ButterbachBahl, K. (2014). The increasing distribution area of zokor mounds weaken greenhouse gas uptakes by alpine meadows in the Qinghai-Tibetan Plateau. Soil Biology and Biochemistry, 71, 105-112. 
7. Smith, K. A., Ball, T., Conen, F., Dobbie, K., Massheder, J. R. (2003). Exchange of greenhouse gases between soil and atmosphere: interactions of soil physical factors and biological processes. European Journal of Soil Science, 69(1), 10-20.

8. Zhang, W., Mo, J. M., Yu, G. R., Fang, Y. T., Li, D. J., Lu, X. K., Wang, H. (2008). Emissions of nitrous oxide from three tropical forests in Southern China in response to simulated nitrogen deposition. Plant and Soil, 306(1-2), 221-236.

9. Aronson, E. L., Helliker, B. R. (2010). Methane flux in non-wetland soils in response to nitrogen addition: a meta-analysis. Ecology, 91, 3242-3251,.

10. Yue, P. Li, K. H., Gong, Y. M., Hu, Y. K., Mohammat, A., Christie, P., Liu, X. J. (2016). A five-year study of the impact of nitrogen addition on methane uptake in alpine grassland. Scientific Reports, 6, 32064.

11. Tilman, D., Knops, J., Wedin, D., Reich, P., Ritchie, M., Siemann E. (1997). The influence of functional diversity and composition on ecosystem processes. Science, 277(5330), 1300-1302.

12. Zeng, J., Liu, X. J., Song, L., Lin, X. G., Zhang, H. Y., Shen, C. C., Chu, H. Y. (2016). Nitrogen fertilization directly affects soil bacterial diversity and indirectly affects bacterial community composition. Soil Biology and Biochemistry, 92, 41-49.

13. Xu, W., Zhao, Y.H., Liu, X J., Dore, A. J., Zhang, L, Liu, L., Cheng M. M. (2018). Atmospheric nitrogen deposition in the Yangtze River basin: Spatial pattern and source attribution. Environmental Pollution, 232, 546-555.

14. Liu, C. Y., Zheng, X. H., Zhou, Z. X., Han, S. H.,Wang, Y. H., Wang, K., Liang,W. G., Li, M., Chen, D. L., Yang, Z. P. (2010). Nitrous oxide and nitric oxide emissions from an irrigated cotton field in Northern China, Plant and Soil, 322, 123-134.

15. Jiang, X., Cao, L., Zhang, R. (2014). Changes of labile and recalcitrant carbon pools under nitrogen addition in a city lawn soil. Journal of Soils Sediments, 14, 515-524.

16. Shang Q. Y., Yang X. X., Gao C. M., Wu P. P., Liu, J. J., Xu, Y. C., Shen, Q. S., Zou, J. W., Guo, S. W. (2011). Net annual global warming potential and greenhouse gas intensity in Chinese double ricecropping systems: a 3-year field measurement in longterm fertilizer experiments. Global Change Biology, 17(25), 2196-2210.

17. Zhu, X., Burger, M., Doane, T. A. and Horwath, W. R. (2013). Ammonia oxidation pathways and nitrifier denitrification are significant sources of $\mathrm{N} 2 \mathrm{O}$ and $\mathrm{NO}$ under low oxygen availability. Proceedings of the National Academy of Sciences of United States of America, 110(16), 6328-6333.

18. Ying, J. Y, Li, X. X., Wang, N. N., Lan, Z. C., He, J. Z., Bai, Y. F. (2017). Contrasting effects of nitrogen forms and soil $\mathrm{pH}$ on ammonia oxidizing microorganisms and their responses to long-term nitrogen fertilization in a typical steppe ecosystem. Soil Biology and Biochemistry. 107, 10-18]
19. Chen, S., Hao, T. X., Goulding K., Misselbrook, T., Liu, X. J. (2019). Impact of 13-years of nitrogen addition on nitrous oxide and methane fluxes and ecosystem respiration in a temperate grassland. Environmental Pollution, 252, 657681.doi.org/10.1016/j.envpol.2019.03.069 